Nathiqiyyah : Jurnal Psikologi Islam

\title{
PENGARUH MEDIA SOSIAL TERHADAP POLA PIKIR MASYARAKAT
}

\author{
Tafsiruddin \\ STAI Diniyah Pekanbaru \\ tafsiruddin123@gmail.com
}

\begin{abstract}
Abstrak
Adanya media sosial sebenarnya merupakan bentuk terwujudnya kemajuan dalam tekhnologi informasi dan komonikasi, media sosial memiliki pengaruh yang berbeda-beda terhadap individu seseorang, karena manusia satu dengan yang lain tentunya memiliki pemikiran yang berbedabeda, meliki sikap yang tidak sama, cita-cita dan keinginannya pun juga tidak sama, ketika mereka melakukan kerjasama dalam sosial kehidupan sehara-hari maka perbedaan itu sebagai penunjang untuk memperoleh kesempurnaan dalam hubungan sosialnya. Saat ini manusia sangat dimudahkan dalam melakukan komunikasi secara virtual, manusia satu dengan yang lainnya dapat memanfaatkan berbagai macam medisa sosial untuk di jadikan sebagai alat berkomunikasi, memberikan iformasi kepada sahabat, saudara hinga jama'ahnya, kita sebagai dosen prodi pengembangan masyarakat islam rasanya memiliki tanggung jawab besar atas kondisi keadaan masyarakat pada saat ini, dimana masyarakat secara umum kadang kala mereka menelan seutuhnya apapun informasi yang diperoleh dari media siosial, oleh karena itu kita sebagai orang akademisi, pendakwah, harus bisa memahamkan kepada manusia secara umum bahwa ambillah informasi-informasi yang positif, yang sekira memberikan kontribusi kemanfaatan terhadap pola kehidupan kita, pola pemikiran kiata.

Media sosial adalah salah satu media sosial dikalangan masyarakat baik muda ataupun tua pasti mereka mengenal apa itu facebook. Seperti yang diketahui, facebook sudah menjadi bagian dari kehidupan dizaman masa kini, Facebook merupakan media sosial yang sangat dikenal dan dipahamai oleh masyarakat belahan dunia, dalam media facebook manusia dapat menuangkan keingannya dan gagasannya untuk disampaikan kepada teman-temannya sehingga masyarakat yang tidak dikenal secara luas, dengan demikian maka sangat menjadi penting bagi para da'i dalam menyebarkan dakwah islamiyahnya, bila para mubaligh mau menuangkan gagasan dakwah dan pengatauhan agamanya pada media sosial berupa facebook atau yang lainnya tentu ini merupakan seuatu yang sangat positif untuk kemajuan dakwah Islamiyah, karena disadari atau tidak media sosial akan memberikan dampak pada masyarakat, dapat mempangarui pola fikir masyarakat secara menyeluruh.
\end{abstract}

Kata kunci: pengaruh media sosial dan pola fikir masyarakat.

\section{A. Pendahuluan}

Segala puji bagi Alloh atas limpahan rahmat dan hidayahnya kepada kita bersama, atas limpahan rahmat tersebut sehingga kami dapat melakukan penelitian untuk memperoleh pengalaman dan menambah wawasan ilmu, malakukan penelitian merupakan aktifitas yang 
sangat mulia bagi seorang dosen, dosen memiliki tanggung jawab atas kemajuan ilmu pengetahuan, seoarang dosen mau tidak mau mereka harus melakukan riset yang dapat menghasilkan sebuah penemuan baru atau ilmu baru sehingga dosen memang betul-betul memiliki kredibelatas yang baik sesuai dengan jati dirinya.

Dalam penelitian ini nanti diharapkan mendapatkan hasil yang dapat memberikan gambaran - gambaran persoalan yang terjadi sehingga apa yang peneliti dapatkan bisa menjadai sebuah pengetahun baru, informasi baru yang dapat memberikan jawaban-jawaban atas persoalan media sosial pada lingkungan sebuah masyarkat yang ada di kota pekanbaru, dimana masyarakat pada saat ini cukup komplek dengan adanya media sosial yang luar biasa perkembangannya, mereka cukup cerdas terhadap keadaan fakta-fakta media sosial, mereka dapat menentuakan pilihan-pilahannya, dengan demikian dalam menentukan sebuah pilihan dalam pemanfatan media sosial harus tepat, artinya jangan sampai media sosial itu disalah gunakan yang dapat berdampak tidak baik bagi para penggunanya.

Demikian yang dapat kami sampaikan, semoga hasil penelitian ini bisa bermanfaat dan dapat dijadikan sumber rujukan dalam menambah reverensi dan menambah wawasan keilmuan untuk memperkaya diri, agar kita semua menjadi insan yang lebih bermanfaat dalam kehidupan bermsayarakat. Kami harapkan masukan dari segenap para pembaca dan saran yang bersifat membangun, mengkoreksi terhadap hasil penelitian ini agar kedepannya bisa memberikkan hasil penelitian yang lebih baik.

\section{B. Metode penelitian}

Bagi peneliti ketika melaksanakan penelitian, sebelum meneliti mereka harus faham terhadap metode penelitian yang akan dipakai, setelah memahami mereka bisa menentukan mana metode yang tepat untuk digunakan dalam penelitiannya, dengan demikian diharapkan penelitian yang dilakukan memang betul-betul dapat kredibel dan memberikan hasil penelitian yang dapat dipercaya, dalam penelitian lapangan tidak akan terlepas dari pertanyaan-pertanyan, tidak terlepas mengobservasi terhadap persoalan yang terjadi, peneliti harus menemukan berbagai macam data, data primer maupun data sekunder, data merupakan sesuatu yang ada, nampak oleh panca indra manusia, buktinya secara fisik ada, data yang baik akan memberikan hasil penelitian yang baik pula, dengan adanya gambaran data yang jelas maka sebuah kesimpulan dapat dilakukan, data yang baik sebagai dasar untuk melakukan evaluasi terhadap apa yang sudah diperoleh (Maleong, 2010:157)

Setiap penelitian dapat dipastikan menggunakan metode yang sudah dintetukan dan metode tersebut akan disesuaikan dengan keadaan model penelitiannya, pada riset saat ini peneliti menggunakan metode kualitatif dengan analisis deskriptif, pengumpulan data dengan cara melakukan observasi, pengamatan atas kejadian-kejadian yang sedang dialami oleh objeknya, mengobsevasi bentuk aktifitas kegiatan-kegiatan yang dilakukan oleh masyarakat (Sugiono, 2013:309). Aktifitas masyarakat bisa jadi akan berubah-rubah, perubahan tersebut bisa terjadi karena terpengaruai oleh kondisi keadan waktu, tempat, bahkan terpengaruhi oleh kemajuan gejed yang semakin canggih dan mudah untuk digunakan oleh masyarakat, dengan 
kemudahan dalam hal pengoprasional alat digital tersebut bisa memungkinkan aktifitas yang dilakukan berganti-ganti.

Observasi adalah keterlibatan langsung seorang peneliti dengan keadaan objek penelitiannya, kegiatan yang berlangsung setiap hari atau pun tidak, peneliti dalam observasi harus selalu mengikuti adanya kegiatan-kegiatan yang berlangsung, sehingga memberikan informasi secara langsung, karena penelitinya ikut terlibat, dan memberikan manfaat pengalaman pada proses penelitian yang sedang berlangsung, jadi metode kualititatif dengan analisis deskriptif sangat efekti dilakukan pada penelitian-penelitian yang bersifat lapangan dan kemasyarakatan, sementara objek penelitiannya dapat dikategorikan menjadi tiga komponen, yaitu, tempat, pelaku dan aktivitas kegiatan (Sugiono 2013:313). Dalam penelitian yang mengangkat tema "Pengaruh Media Sosial Terhadap Pola Pikir Manusia" peneliti berharap akan mendapatkan gambaran dan data-data yang jelas sehingga penelitian ini kan bermanfaat.

\section{Peran Media Sosial}

Secara kontek media sosial dapat dipahami sebagai alat untuk transformasi segala bentuk informasi yg mungkin terjadi, Media sosial ini memiliki kemanfaatan untuk membantu setiap individu seseorang untuk dapat berkumunikasi di seluruh belahan dunia, koneksi internet menjadi faktor utama penyambung komunikasi di media sosial, bahkan menjadi favorit, media social dapat memudahkan manusia untuk berkomunikasi dan interaksi secara online. Media sosial juga membantu manusia memahami dunia dengan mudah dan cepat dalam mengetahui informasi perkembanggan dunia.

Media sosial yang berkembang pada saat ini tidak terlepas dari bagian sebuah teknologi yang ada jika manusia tidak dapat memanfaatkannya sebagaimana mestinya maka media sosial seperti facebook, twitter, whatsapp grup akan menjadi momok bagi para pengguna itu sendiri, namun sebaliknya jika media sosial digunakan sebagai media untuk memudahkan manusia dalam mendapatkan informasi yang positif atau memberikan informasi yang bernanfaat maka media sosial menjadi sesuatu yang sangat berguna, dengan adanya media tersebut orang akan mudah memperoleh iformasi dan dapat memberikan inforamasi apa saja dengan cepat (Sukosusilo 2008:105). Disisi lain banyak kemanfaatan yang bisa diambil oleh pengguna, karena setiap pengguna dapat menjalin komunikasi dengan kolega, sahabat, saudara dengan cepat dan mudah, efisien waktu dan tenaga, hal seperti inilah yang harus dipahami oleh setiap pengguna. Berbeda dengan media tradisional klasik membutuhkan biaya yang banyak, membutuhkan waktu yang lama contohnya seperti media berupa surat kabar yang tradisional atau media cetak berupa koran dan majalah.

Teknologi internet dan gadget seperti handphone saat ini semakin maju dan berkembang, dengan seiring perkembangan alat gadget tersebut maka otomatis media sosial juga berkembang, teknologi berkembangan sesuai dengan tuntutan zaman, kemajuan SDM nya, media sosial merupakan bagian dari teknologi yang berkembang pesat, hampir setiap orang dewasa diperkotaan sudah memiliki alat canggih berupa Smartphone atau laptop, alat ini dengan mudah dikendalikan oleh manusia, namun bila manusia tersebut salah mengendalikan maka akan 
memberikan pengaruh yang yang tidak baik, fenomena-fenomena semacam inilah yang harus dipahami oleh para pengguna.

Media sosial yang biasa disebut orang dengan istilah medsos merupakan media yang bersifat online, dengan keberadaan media online tersebut manusia dengan mudah berpartisipasi dan memberikan informasi didunia maya namun nyata, karena manusia dapat menciptakan sebuah jaringan yang dapat diakses oleh kolega atau pengguna lainnya, yang jelas media sosial saat ini dapat mendukung aktivitas manusia, berdakwah, berbisnis, menjalin hubungan silaturahmi, membangun kerjasama, semua dapat dilakukan secara mudah, sehingga hari ini mestinya manusia menyadari hal itu sehingga media sosial akan memberikan nilai positif bagi setiap pengguna dan media sosial juga dapat mengubah bentuk manusia menjadi dialog interaktif (Susilo 2008:106), seperti yang dilakukan oleh kalangan ulama-ulama militan, para mahasiswa, para akademisi hingga kaum santri, hari kita dapat menyaksikan secara nyata bahwa tidak hanya orang-orang yang sekolah husu dibidang tehnologi saja yang dapat mengoprasionalkan alat gejed media sosial dengan lancer, tetapi siapaun sebenarnya dapat mengoprasionalkan alat gejed itu dengan mudah, terbukti yang terjadi dilapangan secara umum, anak-anak kecil yang belum paandai baca dan tulis saja mereka mampu membuka gejed media sosial berupa hinpohne, si anak-anak ini bisa melihat, mendapatkan hiburan, mendapatkan informasi yang sebenarnya mereka tidak faham apa informasi tersebut.

Jaringan sosial merupakan situs dimana setiap orang bisa membuat website pribadi, kemudian dapat terhubung dengan teman-temannya untuk berbagi informasi dan berkomunikasi, jaringan sosila terbesar antara lain adalah facebook dan web. Dengan itu manusia bisa cepat mengakses media sosial yang dapat mengabadikan terjadinya fenomena besar terhadap arus informasi, jika untuk memiliki media tradisional seperti televisi, radio tentunya membutuhkan modal yang besar. Kita sebagai pengguna sosial media dan aplikasi yang sudah tersedia dengan bebas bisa digunakan untuk mengedit, video, gambar, grafis dan berbagai model bisa kita lakukan, dalam media sosial.

Media sosial merupakan jaring sosial yang menyediakan fitur-fitur menarik serta mudah digunakan oleh masyarakat secara umum, media sosial juga menjadi sarana untuk menemukan kembali sahabat-sahabat yang hilang jejak karena faktor jangkauan tempat tinggal yang sangat jauh, atau sahabat yang sudah lama tidak pernah berkomunikasi, bahkan dengan media sosial seseorang dapat menemukan teman-teman baru lagi, teman baru ini tentunya dapat dijadikan sahabat baru sejati, sehingga dapat membantu sewaktu-waktu dibutuhkan, maka dengan demikian media sosial dapat menyambung dan mempererat silaturahmi antar umat manusia. Media Sosial juga banyak dimanfaatkan untuk bisnis online hingga aksi kriminalitas yang sekarang ini marak di dunia maya.

Media sosial merupakan alat yang dapat digunakan untuk membengaun komunikasi yang besifat kontiyo terus menerus, komunikasi yang bisa dilakukan oleh masyarakat tentunya berbeda-beda, tergantung apa yang di inginkan oleh masyarakat tersebut, kalo masyarakat menginkan membuat sebuah jejaring yang dapat menghasilkan sebuah profit, tentunya mereka akan melakukan apa yang menjadi misinya bisa terwujud, kalo misinya agar dakwah Islamiyah 
tersampaikan kepada masyarakat secara luas, maka media sosiallah yang menjadi perpanjangan tangan dari sebuah misi tersebut, hal semacam inilah yang harus dipahami oleh masyarakat bahwa alat jaringan komunekasi berupa medsos ini bisa membantu untuk melaju lebih cepat.

\section{Pengaruh Media Sosial Pada Masyarkat}

Media sosial merupakan alat yang dapat digunakan untuk promosi dan menyampaikan informasi yang sangat efektif, karena media tersebut dapat langsung diakses bagi siapa saja yang ingin memperoleh informasi, dengan demikian media social seperti website facebook, whatsapp grup sangat mempangaruhi terhadap pola pikir masyarakat, gaya hidup masyarakat, karena memang media sosil memiliki banyak manfaat.

Masyarakat yang menjadi kelompok sekumpulan manusia tentunya saling berintraksi dan saling berkomunikasi dalam waktu yang sama pada tempat yang berbeda, dengan adanya media sosial, mereka mampu berkomunikasi dengan baik yang saling menguntungkan, mereka dapat bertukar informasi menggunakan media sosial sehingga mereka dapat membangun jaringan bisnis dengan produktif, dengan ada nya media sosial berupa whatsapp grup inilah manusia menjadi terpangaruhi kehidupannya untuk menjadi lebih produktif.

Ketika berbicara media sosial dihadapkan pada pola hidup manusia, maka manusia harus dapat memilih dan memilah, mana yang dapat menunjang terhadap perbaikan hidup dangan apa yang justru menjadi momok dalam hidup, ketika manusia dapat mengambil sisi manfaat positifnya yang seperti inilah yang diharapakannya dan tidak sebaliknya hanya prioritas yang ambil kemanfaatan dari sisi negatifnya. Diera modernisasi pada saat ini masyarakat sangat mudah dalam mengunakan media sosial, lebih-lebi bagi kaum muda, mereka bisa dikatakan cepat tangkap terhadap kemajuan media sosial, kemajuan alat digital, sehingga mereka dengan sangat mudah untuk dapat menggunakan alat digital dengan cepat, mengakses sosial media yang terkoneksi dengan internet secara cepat.

Perubahan sosial dalam kehidupan hari ini kita akan mudak menyaksikan secara seksama, bahwa manusia sangat terpengaruh oleh gadget dan media sosial, bagaimana tidak, saat ini manusia mulai dari usia anak-anak hingga tua, mereka senantiasa berdampinggan dengan alat gadget dan alat media social, artinya manusia sudah terpengaruhi dengan adanya media sosial dan gadget ini. Jika demikian yang terjadi dengan adanya bekal akal sehat dan sempurna yang allah limpahkan kepada manusia, maka manusia harus pandai memilihnya, Karena manusia akan di mintai pertanggung jawaban, sebagaimana firman Allah:

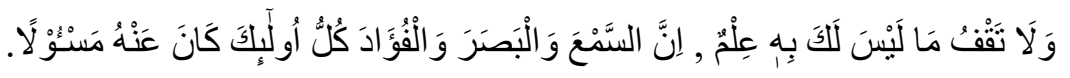

Artinya, Dan janganlah kamu mengikuti apa yang kamu tidak mempunyai pengetahuan tentangnya. Sesungguhnya pendengaran, pengelihatan dan hati, semuanya itu akan di mintai pertanggung jawabannya. QS, Al-Isra, 36.

Ayat ini memberitaukan kepada manusia apa saja yang sudah diketaui ilmunya dan jangan lakukan apa yang tidak didasari dengan sebuah pengetahuan, apapun yang dilakukan oleh manusia akan dimintai pertanggung jawaban sekalipun itu hanya perbuatan pandangan mata. 
Di era digitalisasi saat ini memang sangat mempengaruhi terhadap pola pikir masyarakat, pengaruh pada pola pikir positif maupun negatif, gaya kehidupan masyarakat menjadi berubah secara derastis itu terlepas dari efek kemajuan alat digitalisasi, oleh karena itu yang terpenting adalah bagaimana alat digital ini di fungsi kan sebagaimana mestinya, sesuai norma-norma agama, selaras dengan norma budaya lingkungan, dari hasil penelitian membuktikan bahwa manusia saat ini tidak terlepaskan dari kehidupan era digital, hampir setiap manusia memiliki alat komunikasi berupa handphone, di handphone tersebut mereka dapat mengakses segala informasi melaui media sosialnya berupa website, facebook sampai ke whatsapp grup.

Penguna media sosial hari relative cukup besar, walaupun tidak ada data statstik yang memastikan berapa manusia yang menggunakan media sosial, namun dapat kita lihat setiap kita bertemu kawan, saudara, orang yang tidak kenal sekalipun, ternyata semua dapat dipastikan memiliki alat komunikasi digital, inilah yang menjadi dasar kuat bahwa penggunan alat gadget cukup besar. Media sosial sangat dapat mempengaruhi terhadap prubahan sosial masyarakat, dimana media tersebut dapat memberikan informasi secara cepat, bila informasi yang di akses benar maka akan berpanguruh menjadi manusia yang baik, bila informasi yang di akses perkara yang buruk maka akan mempengaruhi pada masyarakat tersebut menjadi orang buruk.

Fenomena masyarakat keadaan secara umum mereka ada yang mudah terpengaruhi ada yang tidak, tetapi masyarakat pada hakikatnya Merika menginginkan sebuah perubahan,sebuah kemajuan, mereka tidak ingin desebut sebagai orang yang tertinggal selangkah dalam hal apapun temasuk maslah penguasaan alat canggih seperti gejed. Fenomena ini sering kita temukan di tengah-tengah kehidupan, masyarakat berprepsi bahwa jati dirinya orang yang mampu, orang yang hebat, walu itu sebatas sesuatu yang ada dibenak kepala manusia, sebenarnya manusia tidak boleh bersikap takabbur, sombong, sok paling hebat, jika manusia itu berpresepsi demikian maka akan berakibat meraka akan tidak percaya atas kemampuan orang lain, prsepsi seperti ini sebenar sesuatu yang tidak baik dalam pandangan islam, hal ini sebagai sabda nabi Muhammad saw:

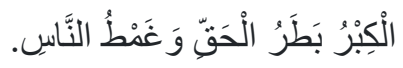

Artinya, sombong itu menolak kebenaran dan merendahkan manusia lainnya.

Keadaan masyarakat yang terganbarkan dalam hadis diatas memang betul-betul ada dan menjadi sebuah keadaan buruk yang dapat mengakibatkan kerugian bagi manusia, meanusi yang mengalami keadaan model seperti ini akan berakibat mereka tidak mau memparbaiki diri, tidak mau belajar mencari wawasan keilmuan yang lebih banyak lagi, perasaan takabbur hanya sebuah penyakit yang melekat pada manusia, kalo itu dianggap sebuah penyakit maka manusia harus mencarikan obat, agar sikap takabbur tersebuat cepat menghengkang dari benak pemikiran manusia.

Manusia pada dasarnya dilahirkan dalam keadaan nya suci, lingkungan akan dapat mempengaruhi keadaan manusia, jika lingkunnagan baik, pergaulannya baik, maka prilakunya menjadi baik, pemikirannya juga menjadi baik, namun sebaliknya jika keadaan suasana lingkungan masyarakat tidak baik, maka akan berpengarauh terhadap manusia yang hidup dan 
bergaul pada lingkungan tersebut menjadi tidak baik.fenomona yang seperti ini mestinya menjadi pelajaran bagi siapaun, agar hidup ini terjebah pada pola hidup yang hanya merugikan manusia itu sendiri, dinilai dari sisi dunia mereka rugi, ruginya karena dalam hidupnya hanya memperbanyak dosa. Apalagi jika dinilai deri kehudupan akhirat kelak nanti, manusia yang bermaksiat akan berakibat mendapatkan siksaan yang sangat pedih.

Fenomena keadaan masyarakat sebenarnya dapat dikelompokkan menjadi dua, masyarkat klasik dan modern, masyarakat klasik maupun modren semua pola fikirnya dapat terpengaruhi oleh situasi dan keadaan, untuk lebih lanjut dapat dipahami dalam penjelasan-penjelasan berikut ini:

Pertama, Masyarakat klasik berbicara masyarakat klasik tentu tidak lepas dari zaman dan masa, masa klsik dapat dipahami masa dimana kemajuan secara tehnologi belum terjadi atau tidak canggaih, dan masyarakat klasik merupakan masyarakat yang hidup dimasa lampau jauh, berangkali kita harus melihat jauh kebelakang bahwa pada masa klasik tidak ditemuan kemajuan-kemajuan tehnologi canggih yang terjadi, adanya alat-alat yang bersifat manual seperti pada nabi, zaman sahabat dan tabi'ien belum ada nuklir, belum ada boom, alat perang adanya baru sebatas pedang, busur panah, kedaraan perang yang adapun masih berupa hewan jaran, melaksankan segala aktifitas sesuatu masih dengan cara manual, ketika semua masih serba manual tentu akan berpengaruh tehadap terhadap gerakan dan tindakan yang dilakukan menjadi lambat, waktu dan tenaga manusia banyak yang tersita, dengan waktu yang Panjang untuk beraktifitas tetapi menghasilkan sesuatu yang minim atau sedikit.

Pikiran manusia lebih cendrung pada tarap biasa-biasa saja, tidak ada keinginan yang nampak utuk menjadi orang yang maju. Istilah klasik ini sebenarnya identik kepada zaman yg tertinggal masalah kemajuan tehnologi dan kemajuan inprastruktur. Namun untuk kemajuan islam Dalam perkembangannya sebenarnya dapat kita lihat dari hijrahnya nabi muhamad dari mekkah menuju ke kota Madinah, sementara itu istilah klsaik dalam perkembnagan islam tercatat mulai tahun $650 \mathrm{M}$ sampai $1000 \mathrm{M}$, atau hingga abad 12 an, memang pada waktu itu islam disebarkan dan didakwahkan dan di informasikan masih dengan cara langsung, dari guru ke murid, satu kitab harus digunakan oleh orang banyak, sebagai mana islam berkembang di tanah air para ulama-ulama timur tengah mereka harus masuk ke wilayah Indonesia mulai dari pulau jawa, Sulawesi hingga Sumatra, semua mengunakan kapal yang berangkali belum ada mesin penggeraknya, mereka berdakwah melalui konsep berdagang terlebih dahulu, sehingga para ulama kenal dengan para pembelinya, lalu para pembei inilah yang menjadi salah satu sasaran dalam dakwah islam. Dalam sejarah mencatat sebenarnya pada masa kepemimpinan sahabat umar islam juga sudah berkembang ke berbagai wilayah seperti jazirah arab, mesir, siriya dan palistina, sahabat umar merupakan sahabat yang menjunjung tingggi dan mengikuti akhlak nabi Muhammad Saw dalam menjalankan tugasnya sebagi pengganti nabi atau kekholifahanya (Muhamad nurhakim 2003:05).

Keadaan tehnologi ditanah air sebenarnya juga dapat dilihat dari zaman sebelum Indonesia merdeka, pada masa itu orang Indonesia demi memperjuangkan kemerdekaanya mereka harus membuat alat perang dari bamboo, bambu-bambu mereka runcingkan, dan pohon bamboo 
kunimg itu bukan alat sembarangan tetapi merupakan pohon yang memili keistimewaan, diruncingkan bisa tajam, model nya tedak mudah patah, dan mujarap ketia mengenai sasarannya. Alat kelasik dan manual sekalipun pada saat itu dapat mempengaruhi pola pikir masyarakat menjadi cerdas, terbukti orang-orang pada saat itu menggunakan mambu kuning sebagai alat yang sakti untuk melumpuhkan musuh-musuhnya.

Kedua, masyarakat modern masyarakat modern merupakan masyaratat yang saat hidupnya mereka merupakan masyarakat yang menjumpai kecangihan-kecanggaihan alat tehnologi, alat digitalisasi yang luar biasa, kemajuan ekonomi yang pesat, kalo dilihat dari kecanggihan tekhnologi zaman modren mulai dari akhir abad ke 19 hingga saat ini abat ke 20 an, dimana pada zaman tersebut banyak kemajuan-kemajuan tehnologi yang dapat disaksikan oleh masyarakat, bahkan sejarah mencatat senjata nuklir pertama kali dibuat oleh amirika sekatar tahun $1942 \mathrm{M}$. pada saat itu Indonesia belum merdeka, masyarakat indonosei dari semua lini bergerak untuk berusaha bagaimana negara Indonesia ini menjadi negara yang nerdika, tidak dijajah oleh negara lain, dengan di umumkannya jihad pada saat itu masyarakat Indonesia terpengaruhi pola fikirnya bagai merakla harus melawan penjajah, sekalipun orang Indonesia belum meliki alat perang canggih, tetapi mereka memiki keberanian dan semangat tyang tinggi untuk menjadi negaranya menjadi negara yang merdeka.

Mengenal keadaan masyarakat modern hari ini tentunya tidak terlepas dari masa kemajuan dari segi tehnologi, ilmu pengetahuan dan budaya, dengan adanya kemajuan tehnologiyang jenisnya bermacam-macam, mulai dari model leptop secara secara fisik cantic-cantik, memiliki fitur serba ada yang dapat digunakan oleh para dosen, para peneliti dan segenap ilmuan, nampaknya senua tidak terpisahkan dari kemajuan alat gejed dan media sosial, disadari atau tidak media sosial hari ini dapat merubah menset manusia, bagaimana tidak! Dimana-mana orang selalu mengakses media sosial berupa fesbook, wa grup sampai ke websait, mereka tidak mengenal waktu dan kondisi, dan hari ini berangkali orang tidak mengakses media sosial hanya ketika mereka sedang beribadah kepada Alloh, bahkan yang beribadah saja dalam kantong saku masih terdapat media sosial yang sedang aktif, yang kadang kala justru akan mengganggu konsentrasi dalam ibadanya, ini menunjukkan begitu besarnya pengaruh media sosial terhadap masyarakat.

Media sosial di era modern salah satunya adalah TV, dan setasiunnya memiliki jumlah puluhan bahkan ratusan, semua menayangkan program-program andalannya dengan cara tayang non stop, tak mengenal waktu, dan manusia bisa mengakses kapanpuan dan dimanapun, masyarakat dapat melihat berita tentang perkembangan dan keadaan dunia, masyarakat cukup tinggal pencet chenel TV yang di inginkan semua akan muncul dan meberikan informasi dengan waktu yang singkat. Dalam penggunaan media sosial yang bertujuan untuk memberikan hiburan, masyarakat harus dapat memilih mana hiburan yang lebih bermanfaat, jika masyarakat dapat memilih program hiburan dengan baik, maka pola fikir manusia yang terpengaruhi juga pola fikir yang positif.

Media sosial dengan masayarakat modren memang sudah menjadi satu kesatuan yang tidak dapat dipisahkan, dalam hal ini peneliti coba mengklompokkan masyarakat modern di usia 
remaja dan dewasa, pengaruh media sosial terhadap usia remaja memang dapat menjadikan remaja tersebut lalai terhadap kewajibannya, lalai terhadap tugas pokok hidupnya, lebih-lebih pada saat ini di media sosial tersedia progam gim online, gim online faktanya memberikan pengaruh yang luar biasa, peneliti sering menyaksikan banyak anak remaja yang duduk lama diteras, dipinggir jalan hanya untuk bermain gim, mereka lupa sholat, lupa makan, hal yang seperti inilah sangat disayang, bagaimana nasib remaja-remaja masa kini kedepannya, apakah mereka mampu bersaing dalam hidupnya, sehingga kedepan mereka mendapatkan pekerjaan yang layak. Selain itu remaja saat ini juga sering memposting yang bertujuan untuk memberikan informasi tentang dirinya, menggambarkan kedaan yang baru saja dialami, kadang kala waktu mereka habis untuk urusan posting memposting, mereka merasa sudah bterkena, merasa orang hebat, sementara merekan bukan siapa-siapa, skil yang berarti juga tidak ada, kalo sudah demikin suguh eronis, memilukan, hal itu bisa terjadi karena terpengaruhi oleh media sosial yang salah dalam penggunaanya.

\section{E. Kesimpulan}

1. Penelitian ini pertujuan untuk mengukur sejauh mana pengaruh media sosial yang semakin meluas dapat mempengaruhi terhadap pola fikir masyarakat secara umum.

2. Dalam penelitian, peneliti segana menggunakn metode kualitaf dengan harapan hasil temuan-temuan dimasyarakat ememang betul-betul dapat diuji sehingga hasil penelitian dapat jadikan sebagai sebuah penemuan atau informasi beru terkait dengan kemajuan media sosial pada saat ini.

3. Di tengah-tengah kehidupan bermasyarakat secara luas media sosial memiliki peran besar terhadapap keadaan manusia.

4. Jaringan sosial media yang berkembang saat ini dapat dapat memberikan informasi apapun sesuan dengan kehendak oarang yang akan memberikan informasi tersebut.

5. Media sosial yang ada dalam handphone dapat dengan cepat untuk diakses mencari informasi, ataupun memberikan informasi.

6. Media sosial yang memuat berita beraneka ragam isinya, kadang kala tidak jelas siapa orang yang mengendalikannya, siapa orang yang memberikan informasi.

7. Dari data yang peneliti dapatkan media sosial sangat mudah mempengaruhi pola fikir masyarakat, lebih-lebih bagi masyarakat tertentu yang tidak mau menyeleksi apa informasi yang sebenarnya.

8. Informasi baik atau buruk, benar atau hoax, semua dapat disebarkan melalui media sosial dengan cepat.

9. Masyarakat harus jeli atas segala informasi yang didapat melalui media sosial, agar masyarakat tidak terjerumus dan tidak terpengaruhi atas segala informasi yang dapat merugikan manusia.

10. Disisi lain media sosial akan memberikan nilai positif bagi para penyebar kebaikkan, mereka akan mudah untuk menyampaikan kebenaran di tengah masyarakat. 
11. Di akaui atau tidak bahwa media sosial dapat mempengaruhi pola fikir masyarakat, bahkan pola hidup manusia pun bisa terpengaruhi dan dapat berubah dengan cepat.

12. Masyarakat yang hidup dizaman nabi, zaman para shabat, semua akal pikirinya dapat terpengaruhi dan yang mempengaruhi selain doktrin ajaran yang ditrimanya juga situasi keadaan zamannya.

13. Pada era modern dimana alat media sosial semakin canggih, dan kecanggihannyalah yang dapat mempengaruhi bagi setiap penggunanya.

14. Karena media sosial sudah dapat dipastikaan bisa mempengaruhi bagi setiap pengunanya, maka setiap pengguna harus bisa memilih mana yang baik dan mana yang tidak baik, sehingga pengguna tidak mudah terjerumus kepada hal-hal yang tidak di inginkan.

\section{Daftar Pustaka}

Al-Qur'an Kemenag RI.

Kitab Hadis Shohih Muslim, Bairut.

Bungin, Burhan. 2007. sosiologi komunikasi, Jakarta, kencana

Susilo. S. 2008. sosiologi komunikasi, Surabaya, janggala pustaka utama.

Maleong, L. J. 2010. metode penelitian kualitatif, Bandung, PT. Remaja Rosdakarya.

Sugiono. 2013. metode penelitian kombinasi. Bandung, alfabeta.

Soekanto. S. 1990. Sosiologi Suatu pengantar, PT. Raja Grafindi Persada, Jakarta

Nurhakim. M. 2003. sejarah dan peradaban islam, malang UMM Pres. 